\title{
Brief Discussions on How Make-Believe Play Influences Children'S Development
}

\author{
Yong-xian Jin \\ College of Mathematics, Physics and Information \\ Engineering \\ Zhejiang Normal University \\ Jinhua Zhejiang, China \\ jyx@zjnu.cn
}

\author{
Meng-qi Jin \\ Curriculum Teaching and Instruction \\ The Education University of Hong Kong \\ Tai Po Hong Kong, Hong Kong \\ s1117896@s.ied.edu.hk
}

\begin{abstract}
The article focuses on the relationship between make-believe play and the development of children in light of the results of previous researches on the Vygotskian Approach. Since play acts as a crucial part of the children's growth, children social with others and learns to interact through language and role play. As a source of development or prerequisite, makebelieve play has a variety of positive effects on children. However, children have to learn academic knowledge which makes basic foundation for their study life in the future, and if they spend too much time on play, they will have no time to learn new knowledge, teachers are struggle to arrange the students' learning plan. Thus, how to balance the time of playing and learning is a big problem for educators. The article gives examples and evidences to explain why make-believe play makes the contribution to the development of children.
\end{abstract}

Keywords-make-believe play; children's development; academic skill; Vygotskian Approach

\section{INTRODUCTION}

Nowadays, many educators come across the trouble that how to keep the balance between academic skills and play since they concern about children's school readiness and also concern about whether children could catch up with the learning progress in the later academic learning if the children spend a lot of time on playing games [1]. Therefore, play is being replaced by courses which pay attention to promote children's cognitive development, and literacy and reading, in particular, to keep consistent with the requirement of standardized testing [1]. However, Vygotskian argue that, while formal schooling provides the training for these advanced psychological process, play produces important prerequisites for them [2]. Additionally, play is the best way for children to learn new things since they can gain some experience and learn interpersonal skills as well as respect others by sharing and collaborating with peers during the process of make-believe play. So how to solve the dilemma between play and academic skills is urgent. The current paper will talk about why make-believe play can solve the embarrassing situation and make positive effect on children's development.

\section{The AdVAntages of MAKE-BelieVe Play}

Vygotsky ever stated that play helps children find out the rules of personal relationships and encourages children to do better in the process of social interaction. There is no doubt that children should spend lots of time studying how to get hold of enough academic knowledge. It is well-known that children's performances in preschool are not valued by the results of tests or grades, but things begin to change when they come to primary school, children are busy with their homework and they have little time to play. Influenced by traditional concepts that only enter an elite school can students have a good future, they study hard to obtain high grades because they are ranked by the academic performance, and also, to gain more useful skills. But in fact, children can learn academic skills not only by having academic lessons but also by engaging in the make-believe play. So how to make full use of the advantages of make-believe play and why it is so important?

First of all, it offers a safe practice environment to children to experience and think about what to do when they come across troubles; and it also gives chances for them to express their inner emotions, which help teachers to observe whether the children have cognitive biases or not, thus correcting the cognitive biases and facilitating the healthy development of children. Make-believe play gives opportunities for children to find and to solve problems through the simulation scenarios since children will simulate different situations and some of the situations come from real life. In fact, children sometimes play as astronauts, and sometimes act as doctors, and sometimes play as small animals, the inner emotional span of different roles are amazing and children can vent anxiety, depression, and bad mood through the role play. As the famous early childhood educator Chen Heqing ever said that children's knowledge is acquired from experience, but their life is a game, make-believe play is not a simple game, it is the mirror which helps children to know the adults' world. In the game, children can know himself in the comparison with people and things around. The doll acts as herself and she plays the role of her mother. It is a dramatic game that the roles are not constrained by a person; sometimes she can play multiple roles in one game. At the same time, the genuine emotions that children express unconsciously during the process help the teacher to know about them better and this could be conducive to teachers' teaching that teacher could teach students in accordance with their aptitude.

Secondly, it facilitates cultivating many practical skills of children, especially the social skills. In fact, children are encouraged to play not because they can learn new things from it, but because they really enjoy the game and throw 
themselves into it, and then they will experience the feeling of pleasure and enjoyment of mastery which comes with increasing skill [3]. They can practice their communication skills in the make-believe play since there are various kinds of roles and positions, which are required to be developed into different conversations along with the development of the situation. And the make-believe play can cultivate children's sense of cooperation as well; they must learn to negotiate with each other to determine their respective roles as well as topics and contents of activities. Imagine that if two boys want to be "Dad", their arguments will stop the process of make-believe play, so one of them will make the concessions keep the games going on smoothly. Also, make-believe play is an improvisational activity because it offers children with different stimuli and different circumstances to cultivate the children's abilities to make respond to the emergency promptly. And the behaviors that children show in the make-believe play come from imitation. In general, imitation is a crucial way for children to perceive the world and know about others, but not all the things can be learned through imitation. As Elkonin (1978) explained that social roles and the relationship is the core of the mature play, but children cannot only learn by imitating the behaviors of adults, make-believe play gives chances to children to build their own characters and regulations with the help of teachers and parents [4]. The children who spend more time on social games have a better social adaptive capacity as they can understand others' feelings better and even some of them are more advanced in intellectual development. Recently, plenty of evidence shows that children grasp social skills such as interpersonal skills and work-related skills make contribution to early school performance.

Thirdly, it helps children to establish their ethical judgments and express emotions in appropriate ways. For example, in a make-believe play, 'the daughter' gets hurt and 'the nurse practitioner' is binding up the wound while 'the mother' waiting aside anxiously and 'the mother' keep asking the matters which are needed to pay attention to. But then 'the nurse practitioner' is to blame for wrapping the wound too slowly by 'the mother' and 'the mother' pretended to hint 'the nurse' unexpectedly. From this, we can see the child who plays 'the mother' may have wrong cognition that she forced others to show her concerns about 'her child'. It is common to see that children use inappropriate ways to express their emotions, but to help children have healthy emotion situation is the duty of teachers and parents. Actually, children's emotional health is influenced by their developmental ability to grasp the significance, put thought into words and make adjustment to some standard or requirement and so forth [5], and learn to express the emotion appropriately is the fundamental content for children to learn that children should know how to give their opinions and feelings in the ways that they can be understood clearly. What's more, make-believe play gives children chances to have transposition consideration, it is so important that children can think about things in the perspective of others, which will make a real difference to their study life in the future, and children can gradually understand themselves during the comparison with surrounding people and things.
Fourthly, it inspires the imagination and creativity of children. Role play games can let children learn to think from other perspectives. There are not much difference between facts and imagination; role play can further stimulate baby's imagination, which is good for children's brain development. Simulation dialogue can not only deepen the emotional communication with mother, it can also stimulate baby's left brain's language center, If the child's imagination can be conveyed by the natural language expression, left and right brain can be developed greatly, and because of this, role play can stimulate a child's imagination. Children could learn mature thoughts and behaviors by stimulating a variety of roles; it is the educational function of role play. Actually, makebelieve play is a symbolic play, take Ms. Sotto's classroom as an example, children create a fantasy world where their imagination and creativity soars freely, their language expands and their practical skills cultivate as well [6]. During the game, the children rely on imagination to transform the function of the props continuously; for instance, a box can be used as Television and it can be served as a table at the same time. The characters can be changed as well, children can pretend to be a teacher at first, and then become a doctor or seller. The game's plot is changed constantly according to their needs. Generally, children often role-play family scenes and professional staffs which they see very often, such as father, mother, doctor, and policeman and so on. This helps children to know about the basic characteristics of all kinds of occupations and facilitates them to have an insight into the association between themselves and the surrounding world. There are various forms for children to show their fantasy; fantasy can be expressed by plenty of play behaviors, and the performances in divergent thinking task may include fantasy elements [7]. Children create their unique fantasy world through the process of role play and express their inner emotions and expectations towards beautiful things or create their own imaginative future with every simple idea either consciously or unconsciously. Two amazing and unique human characteristics are combined through makebelieve play, these properties are the capacity for fantasy and the capacity for and need to, make meaning of our experience [8]. Therefore, the imagination and creativity, as well as divergent thinking skills can be cultivated in the make-believe play. Additionally, it encourages the communication between children and parents. The make-believe play reflects the children's awareness of towards life to some extent. As the closest person to children, parents can observe the child's attitude towards life, and whether he or she is satisfied with the current family life on the basis of the game. Some researchers show that the executive function of children will be developed with the support of parents. Parents can help children to behave better in the make-believe play by encouraging or guiding the children instead of merely taking part in the game. It is better to let children play with their peers since they have more communication with each other, and conflicts and negotiation will happen at the same time. As guides, parents should not interfere too much, but to give enough space for children to better experience the meaning of life. The way to stop the children playing is not advised in the make-believe play, and parents should not use tough ways to correct the children's performances since the role play need not to be realistic, and it 
is more important to help children to understand the roles and to participate in the activity.

The last but not the least, it develops the children's patience to delay gratification. Different from general ways to suit our needs, delay of gratification is a self-imposed ability. Delay of gratification can be defined as "the ability to deny impulse in the service of a goal" [9]. In many cases, children have chances to delay gratification while the teachers and parents are absent, for example, the children should wait for their turn to use toys or props because of the limited toys or they should wait for the chance to play their favorite roles since everyone have the only one role to play. However, delay of gratification is not merely waiting for something because adults ask children to do so, instead, it requests that children have no choice but to delay gratification under the circumstance of no interventions externally. Vygotsky (1966) ever stated that play put forward requirements on the child to behave against immediate impulse (p. 548). And clash usually happen no matter when the children play with their partners or play alone. The children may be entangled in the dilemma that whether to play in accordance with the rules of the game or do something with taking no account of the theme, that means, children have two choices that they can do whatever they want or they should obey rules to follow the guidance to play. But the reality is that children gain more pleasure under the rules than behaving on impulse during the process of make-believe play, so children choose to delay gratification. It seems that people do not cherish the things which they get easily; this principle applies equally to the child as well. Also, delay of gratification is served as a crucial element of emotional intelligence [10]. Emotional intelligence is defined by eight specific competences and delay of gratification is one of them, the left abilities are selfmotivation, impulse control, empathy, hope, regulation of mood and so on and so forth [11]. Therefore, teachers need to set role play hubs in the classroom and provide a variety of topics to encourage children to take part in the make-believe play actively.

Since there are so many benefits of make-believe play, as the most critical people who accompany the children to grow up, parents should give appropriate guidance for students. Firstly, the parents could help the child to use the correct language action to play the role of the story; generally, children love small animals in fairy tales. If parents provide the child with a headdress or a piece of some small toys as props, their performance desire will become very high. And by reciting all the conversations, children's memory could be exercised a lot. Secondly, guide the children to pay attention to the pronunciation of each word when reading or speaking. In fact, to guide the children to gradually understand the content of the work and express them with thoughts and feelings is very crucial for children. Thirdly, parents can help children to edit the fairy tale into the role of small repertoire. Fairy tale is a form of literature and art which children cannot resist. To make the story more interesting, parents should be involved in the performance of their children. This not only helps children to cultivate their perform ability, but also makes a family full of joy. For example, in the 'fisherman and goldfish' story, father can play the fisherman, and mother plays the old woman, and child plays the goldfish. Children can use language to communicate with parents, and this can assists children to understand the story better. Additionally, parents should remind their children to focus their attention while playing role play games. Children should learn to do things carefully and how to expand imagination by practice. It is good for them to develop the good habit of doing things seriously.

\section{THE DILEMMA}

More and more researchers have shown that the mastery of early academic skills can make solid foundations for the accomplishment of later academic learning [12] and help children to adapt the school better [13]. So many educators begin to think about how to solve the problem that children may not have a good grasp of academic skills if they spend most of the time on playing, or they may fall behind their peers who have mastered lots of academic knowledge in the kindergarten. In fact, American national studies on the children's achievement levels in academic learning have indicated that increasing number of kindergarten pupils have not gained the essential skills which are necessary for them to behave well in school life. What's more, the research by Ladd and Price (1987) demonstrated that the situation of child adjust to school depended on his social performances in preschool and the classroom relationship of children and their peers in the in kindergarten [14]; and this adjustment level is decided by the indices of the perceptions, participation, and behavior in school. Correspondingly, these interpersonal interactions indicated the situation of children's later performance and participation during the whole process in kindergarten. Foulks and Morrow (1989) also found that work-related skills such as following instructions and guidance, and comply with teacher requirements, played a crucial role in the success of kindergarten [15]. It seems that the children who take part in the activities actively are more able to concentrate on and are more likely to have better academic performances. However, everything has two sides. Different from other theories, Vygotsky stated that play is more than a reflection of the current development level of children, but most of all, it is a mechanism which can promote the development of children. Play can inspire the children's power and potentials although the children are unaware of, especially the make-believe play. Hence, the key to solving the problem lies in how the teacher guides the students to learn new things through role play.

\section{CONCLUSION}

From my point of view, role play is served as an essential part of children's development that many famous educators emphasize it, such as Montessori, Piaget and etc. The reason why make-believe play is crucial to children's growth is that it is considered as the therapy that children can not only get in touch with the world but also know about their own potentials. What's more, play is the child's nature; we cannot think about children's problems in the perspective of adults and force them to achieve our expectation. The duty of teachers is to educate the whole child - head, heart and hands and make full use of their nearest development zone to assist them in developing specific skills and completing some tasks. As facilitators, teachers and parents should establish a safe environment for children to develop practical skills and imagination as well as creativity, to express their emotions appropriately, to have 
healthy emotions, and the most important thing is to help children find their potentials. Vygotskian thinks that makebelieve play can cultivate the prerequisites for children to learn academic skills; however, there are few types of research' results confirm that make-believe play can make the contribution to children's academic learning, maybe in the future, more studies should be conducted on this topic.

\section{ACKNOWLEDGMENT}

At the point of finishing this paper, I'd like to express my sincere thanks to all those who have lent me hands in the course of my writing this paper. First of all, I'd like to take this opportunity to show my sincere gratitude to my supervisor, Ms. Jin, who has given me so much useful advices on my writing, and has tried her best to improve my paper. Secondly, I'd like to express my gratitude to my friends who offered me references and information on time. Without their help, it would be much harder for me to finish my study and this paper.

\section{REFERENCES}

[1] Zigler E F, Bishop-Josef S J. The cognitive child versus the whole child: Lessons from 40 years of Head Start, Play= learning: How play motivates and enhances children's cognitive and social-emotional growth. (2006)15-35.

[2] Bodrova, Elena, and Deborah J. Leong. High quality preschool programs: What would Vygotsky say? Early Education and Development.16.4 (2005): 435-444.

[3] Boucher, Jill. Editorial: interventions with children with autism-methods based on play, Child language teaching and therapy. 15.1 (1999) 1-5.

[4] Bodrova, Elena. Make - believe play versus academic skills: a Vygotskian approach to today's dilemma of early childhood education.
European Early Childhood Education Research Journal.16.3 (2008) $357-$ 369.

[5] Denham S A, Blair K A, DeMulder E, et al. Preschool emotional competence: Pathway to social competence? Child development. 74.1 (2003) 238-256.

[6] Leong, Deborah J., and Elena Bodrova. Assessing and scaffolding: Make-believe play.YC Young Children.67.1 (2012) 28.

[7] Johnson, James E. Relations of divergent thinking and intelligence test scores with social and nonsocial make-believe play of preschool children, ETS Research Bulletin Series. 1 (1976) 1-16.

[8] Linn, Susan. The case for make believe: Saving play in a commercialized world, The New Press. 2013.

[9] Goldman, Laurence R., and Michael Emmison. Make-believe play among Huli children: Performance, myth, and imagination, Ethnology. 34.4 (1995) 225-255.

[10] Cemore, Joanna J.and Joan E.Herwig. Delay of gratification and makebelieve play of preschoolers, Journal of Research in Childhood Education. 19.3 (2005) 251-266.

[11] McClelland, Megan M., and Frederick J. Morrison. The emergence of learning-related social skills in preschool children, Early Childhood Research Quarterly. 18.2 (2003) 206-224.

[12] Mullis I.V.S., \& Jenkins, L.B. The reading report card, 1971-1988: Trends from the nation's report card, Princeton, NJ: Educational Testing Service. (1990)

[13] Alexander, K.L., Entwisle, D.R., \& Dauber, S.L. First-grade classroom behavior: Its short and long-term consequences for school performance, Child Development. 64 (1993) 801-814.

[14] Ladd G W, Price J M. Predicting children's social and school adjustment following the transition from preschool to kindergarten, Child development. (1987)1168-1189.

[15] McClelland, Megan M., Frederick J. Morrison, and Deborah L. Holmes. Children at risk for early academic problems: The role of learningrelated social skills, Early childhood research quarterly. 15.3 (2000) 307329. 